\title{
Problem-Based Learning On Students' Critical Thinking Skills In Teaching Business Education In Malaysia: A Literature Review
}

Mohd Nazir Md Zabit, University of Strathclyde, UK

\begin{abstract}
This review forms the background to explore and to gain empirical support among lecturers to improve the students' critical thinking skills in business education courses in Malaysia, in which the main teaching and learning methodology is Problem-Based Learning (PBL). The PBL educational approach is known to have maximum positive impacts in producing professional competencies among graduates in many educational disciplines. However, there is limited discussion about PBL pedagogical approaches implemented in business education. This approach has not been established as a major pedagogical method in schools of business around the world. However, there are a few schools of business that use the implementation of PBL in their curriculum structures. Studies that focused on that issue are implemented in various aspects, courses and using various methodologies. There are various materials which relate to PBL and critical thinking skills. However, in Malaysia, the material is limited because of the lack of research relating to this methodology and lack of research documentations. In Malaysia, the PBL method is only being practised at higher institutions of learning, and it is only limited to certain fields. The analysis of this part tends to discuss PBL in tertiary education, examining the mechanism of the popular educational approach of PBL. The analysis of PBL is intended to see if it may offer any solutions to problems encountered in various education, and to focus on its potential for implementation and impact on critical thinking skills in teaching business education.
\end{abstract}

Keywords: problem-based learning, critical thinking skills, business education, teaching approach, tertiary education

\section{INTRODUCTION}

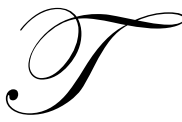

raditional education, including tertiary business education, has been criticized in its achievements to help students develop habits of thinking, research skills, and problem solving abilities that will be vital in order to succeed (Dewey, 1944; Delisle, 1997; Lemke, 2001) and developing intelligences (Tan, 2007) in the ever-changing world of the $21^{\text {st }}$ century. Traditional learning is teacher-centred (Spence, 2004); the teacher provides the student with the correct answer for various circumstances, and student are taught how to use this information as the teachers assign problem applicable for these answers. This type of instruction in higher education for the professions have been criticized for lack of attention to particular issues such as the relevance of subjects, little emphasis on encouraging teamwork, not fully developing skills of enquiry in students, and also for inadequate portrayal of the context of major issues and problem (Boud \& Feletti, 1991: 15). One of the goals of the PBL was to increase students' active learning and decrease their experience of the sort of passive learning that occurs in lecture (Armstrong, 1991). To improve on this, academics seek to reduce the time spent delivering formal lectures while increasing the time students spend on learning tasks and developing critical thinking skills. This literature review will be focused on Problem-Based Learning (PBL) methodology and critical thinking skills, because critical thinking is a basic to learning process (Phillips, 1997) and it also involves a problem solving process (Clarke, 1990). This method to improve students' critical thinking skills gained attention from teaching and learning 
theories, educators, policy makers and researchers because intelligence in the real world involves not only learning how to do things effectively but also more importantly, the ability to deal with novelty and growing our capacity to adapt, select and shape our interactions with the environment.

There are various materials which relate to PBL and critical thinking skills (Chin \& Chia, 2000; Neo \& Neo, 2001; Ward \& Lee, 2002; Kivela \& Kivela, 2005; Tan \& Ng, 2006; Awang \& Ramly, 2008; Yuan et al, 2008). However, in Malaysia, the material is limited because of the lack of research relating to this methodology and lack of research documentations. In Malaysia, the PBL method is only being practised at higher institutions of learning, and it is only limited to certain fields.

\section{WHAT IS PROBLEM-BASED LEARNING AND WHAT BENEFITS MIGHT BE EXPECTED?}

PBL is not a new phenomenon. According to Boud and Feletti (1991), PBL is a methodology that will be used before the classroom concepts are introduced. PBL curriculum as a core in this research was introduced by Howard Barrows (medical education level, McMaster University) and the origin of PBL can be traced to the progressive movement, especially to John Dewey's (1944) belief that teachers should teach by appealing to the students' natural instincts to investigate and create. According to the McMaster model (Barrows \& Tamblyn, 1980), the concept of the PBL method involves three phases which are (i) revealing the problem scenarios, (ii) finding information, and (iii) discussion and new knowledge application to the problems. PBL method stresses that problem solving activities is a style to gain and to apply the knowledge (Barrows \& Tamblyn, 1980). PBL is becoming an increasingly popular term in tertiary education and was first applied in business schools (Kwan, 2000), as more and more educational disciplines implement the teaching and learning approach associated with the terminology, previously believed to be monopolised by medical schools. PBL applies widely to learning in most professional schools and disciplines. In fact, some argue that it is the most significant innovation since the move of professional training into educational institutions (Boud \& Felletti, 1997).

According to Barrows and Tamblyn (1980), PBL is defined as the learning that results from the process of working towards the understanding or resolution of a problem. On the whole, business education program normally uses the traditional business curriculum structure produce one tier teaching method which is the traditional teachercentred approach. The knowledge of business subjects is disseminated via lectures in business coursework classes. Instructors periodically give lectures and by the end of a study session or semester, the assessment of students' performance is made, mainly based on examination. Barrows and Tamblyn (1980) regard this as an important step in which students recall what they already know about a topic, to give them a context for learning (Norman \& Schmidt, 1992; Schmidt, 1983). The current business education system has seen some variations in modes of performance assessment of business coursework. This is usually limited to case study, report submission and presentations which do not depart from teacher-centred approach.

In PBL approach, according to Flint (2007), typically 5-8 students work together in a group. Active discussion and analysis of problems among students enable them to: learn from each other; apply content knowledge to a practical real world problem; learn and practise both individual and group communication skills; evaluate the learning and discovery process they used to achieve their goals and solve the problem.

\section{THE CHARACTERISTICS OF PROBLEM-BASED LEARNING}

The main characteristics of PBL as based on Barrows (1997) provide the teacher with a checklist of features to be designed into courses. These characteristics are: (i) student centred - the students are motivated to be responsible on self-learning. The teacher will act as a facilitator and will help students to make a right decision. This is in line with Margetson's (1991: 45) view of one of the characteristics of PBL. She states that PBL is morally defensible in that it pays due respect to both student and teacher as persons with knowledge, understanding, feelings and interests who come together in a shared educational process; (ii) problem-based - the problem to be used is an ill-structured problem, e.g. the problem in the real world. Enough information will be given to stimulate thinking process in the students' memory and this will involve inductive and horizontal reasoning, and deductive and vertical reasoning to generate hypothesis. The students will face an inquiry learning when the problem is designed (p. 4). This is in line with the PBL characteristic outlined by Savery and Duffy (1995), Boud and Feletti (1991) and Camp 
(1996) that learning is an active and engaged process - anchor instruction and situated learning support this learning theories. Margetson (1991: 45) also share the same view with her view of another PBL characteristic that it encourages open-minded, reflective, critical and active learning; (iii) problem solving - a problem will be used to stimulate effective and efficient development and reasoning skills. The teachers will guide the students at metacognitive level. At the early stage, there will be a modelling of problem solving process and teachers will reduce their role when students start to communicate and make argument with themselves and peers about what they think (p. 4). This feature stated by Barrows is similar to the view of Savery and Duffy (1995), Boud and Feletti (1991) and also Camp (1996) that students will act as meta-cognitive and learning will be focused to solve the thinking skills. To solve the problems, the students will stimulate their self strategy.

The next features of PBL as related by Barrows are; (iv) self-directed - students can justify what they must learn and this is based on their task to solve the problem (p. 5); (v) reiterative - when students are finished with selfdirected learning (search of information needed to solve the problem) they will go back to the problems and will apply a new knowledge that they gain through problem solving. The experience that they gain will be used to construct new knowledge. This is similar to the view of Savery \& Duffy (1995) that learning is the process to structuring the knowledge. PBL is consistent with the principles of constructivism which emphasise that knowledge is constructed through experience; (vi) collaborative - students will collaborate in the problem solving process and will identify learning issues. The student collaboration will occur during self-directed learning when students form a group to solve the learning issue which has been identified (p. 5). This feature is similar to the view of Savery and Duffy (1995), Boud and Feletti (1991) and also Camp (1996) who stated that learning will involve the social deals. The PBL process required group collaborative. The students' thinking, belief, perception and self knowledge will be challenged when they collaborate with other students and this will stimulate cognitive process development.

Other features of PBL as stated by Barrows are; (vii) self reflecting - when the problem is solved, students will make a self-reflection to new information, compared with new problem, make a reflection to face the same problem (for the future), to abstract a concept or a principle, and draw a mind map to show the connection of problem elements and connection of the reason (p. 5). This is similar to another of the PBL characteristics outlined by Margetson (1991: 45), she stated that PBL reflects the nature of knowledge which is complex and changes as a result of responses by communities of persons to problems they perceive in their worlds; (viii) self-monitoring student will monitor, evaluate the progress and self achievement. Self evaluation will be in the form of teacher response, peer group and other evaluation (p. 5) and; (ix) authentic - all the required learning behaviour in PBL includes all the required steps by students and it will be evaluated in real world situation (p. 5).

The features of the learning environment in a PBL curricular stand out as typical in normative texts about PBL and are regarded as essential for enhancing student learning (Barrows, 1997; Boud \& Feletti, 1991; Camp, 1996; Margetson, 1991; Savery \& Duffy, 1995). The features of PBL, as an educational practice will be the same regardless the subject matter or area. A possible conclusion is that since PBL being a flexible way of organizing teaching and learning, there are possibilities for different academic cultures to shape PBL according to their own needs and traditions and to their inherent perspective of learning. Thus, the implementation of PBL does not necessarily mean a new way of thinking about teaching and learning. The academic disciplines are powerful forces in the articulation, maintenance and reproduction of the perspectives, values and beliefs embedded in their cultures. The features by Barrows (1997) also can be helpful in making teaching decisions that support the nature of the content and the range of students.

\section{THE EFFICACY OF PROBLEM-BASED LEARNING IN TERTIARY EDUCATION AND TEACHING APPROACH}

This analysis of this part tends to discuss PBL in tertiary education, examining the mechanism of the popular educational approach of PBL. This analysis of PBL is intended to see if it may offer any solutions to problems encountered in various education, and to focus on its potential for implementation and impact on critical thinking skills in teaching business education. This is much debated and there has been controversy in recent years over the efficacy of PBL as a teaching and learning methodology (Albanese, 2000; Colliver, 2000; Dolmans, 2003; Farrow \& Norman, 2003; Newman, 2003; Newman et al, 2004). Based on Hmelo-Siver (2009), the goals of PBL include helping students develop flexible knowledge; effective problem-solving skills; self-directed learning (SDL) 
skills; effective collaborative skills and; intrinsic motivation. A large number of studies have supported these benefits of PBL, though there has been little research on PBL approaches within business education. In the same way, the advantages of this approach are well documented especially in the medical, engineering, and sciences education, but there is a lack of research into its use in business education.

There have been a substantial number of empirical studies which investigated the implementation and effectiveness of PBL. Through this PBL methodology, students became more motivated (Chan, 2000) and their research became more focused and meaningful. This is supported by Chin and Chia (2000) and Syed Anwar (2002) that PBL methods that involved an identified problem by students were efficient. Students became highly motivated because they treat the problem as their own. The students also became more involved in learning and become more creative and critical (Neo \& Neo, 2001; Morales-Mann \& Kaitell, 2001; Frenay et al, 2007). As for De Graaff and Kolmos (2003), they believed that PBL also helped to increase the consideration of interdisciplinary knowledge and skills. Additionally, PBL has potential to increase the cognitive competitiveness of individuals by eliminating barriers that may inhibit work processes (Yeo, 2007) and encourages students to apply relevant and meaningful information to real-life situation (Tiwari, 2009).

Morales-Mann and Kaitell, (2001) and Du (2006) found that PBL has also been useful in developing management, collaboration and communication skills. Savin-Baden (2000) and Du (2006) conclude that PBL has also helped in improving the meaningfulness of learning. According to Frenay et al (2007), students in PBL curriculum may be better able to learn and recall information and improving engagement.

Summarising and reflecting on the work by Ward and Lee (2002), in "A Review of Problem-Based Learning" who claimed that the PBL process expands students' critical thinking and problem-solving skills while enhancing their creative capabilities; interdisciplinary teaching is appropriate for both vocational subjects, including family and consumer science, and traditional academic subjects. The rationale for PBL derives from findings of the cognitive sciences regarding how we learn. It is founded on the simple premise that problems should precede answers. In PBL, the learning process begins by presenting the learner with an engaging problem, question, or puzzle. Learners discover course concepts for themselves as they explore the problem. However, participating in and exploring the learning event often provides the impetus to engage content and develop skills, just as experts do in practice (Ward \& Lee, 2002).

Other potential advantages for students' learning are claimed for PBL. It is worth considering, for example, other intended learning outcomes for PBL over and above knowledge acquisition; these would include a capacity for SDL, team-working ability (Neo \& Neo, 2001) and autonomous learning (Morales-Mann \& Kaitell, 2001). Specifically, Hmelo-Silver and Lin (2000) used information processing and constructivist theories to examine a component process model of the SDL process and they argued that the students, when faced with a novel problem, must use metacognitive strategies to identify what they don't know and what they need to learn more about to solve the problem. Students also need to figure out what resources they need to remedy their knowledge deficits. Lastly, the new knowledge must be evaluated to determine whether it is the appropriate knowledge and to integrate it with prior knowledge to solve the problem. Hmelo-Silver and Lin (2000) used methods of protocol analysis from cognitive psychology to compare PBL and students' SDL processes on a novel problem-solving task. Hmelo-Silver and Lin (2000) also examined several of the individual component processes in SDL, as well as how well students use new knowledge in problem-solving. The findings showed that PBL students are more likely to identify hypothesis-related learning issues, to develop a well-specified starting point for their SDL in the plan they generate and to integrate new information into their problem solving. Added to this, $\mathrm{Du}$ (2006) shared the opinion that PBL helped in improving SDL capability. Du examined the learning experiences of engineering students of both genders in a problem-based and project-organized learning environment at a Danish university. This qualitative study related an amalgam of theories on learning and gender to the context of engineering education. More importantly, SDL is a core concept in PBL (Silen, 2009). According to Burch (2001), PBL methods promote political, social and cognitive abilities. Students benefit form personal experiences that illustrate collaboration over competition, participation over indifference, listening and deliberation over knee-jerk reaction, and democracy over disillusionment or despotism. Developing these political and ethical sensibilities is as important as fostering cognitive skills. 
Tan and Ng (2006), using the case study method, monitored and documented the performance of pioneer batch students who took up the entrepreneurship programme (designed using PBL) stated that PBL premises on its emphasis of active learning through solving 'real-world' problems as well as its multi-solution approach is likely to have an advantage if positioned as a pedagogical strategy for entrepreneurship education. Yuan et al (2008), provided an explanation that PBL approach, in the context of nursing education actually increased students critical thinking skill more than the lecture approach. They also examined the effect of PBL on nursing students' critical thinking skills. They concluded that PBL students' critical thinking skills did not appear to show significant great development in relation to the deduction, inference and evaluation subscale scores. This argument does not stand up, for many students, the types of active learning like PBL requires is and an unusual experience. One method for assisting students in their learning understanding of the PBL process is to ask them to reflect on the experience of PBL at key points in the process (Major \& Palmer, 2001).

To take another example, PBL helped to promote deep approaches of learning instead of surface approach (Dochy et al., 2003 \& Biggs, 2003). According to Kivela and Kivela (2005) and Du (2006) after exposure to PBL methods, students demonstrated that they were able to take a more pro-active role in their learning, they more readily develop self-management skills in term of their own learning (Maddocks, 2004) and more self-directed in their learning activities. Similarly the students talked about learning in PBL as being both fun and hard at the same time (Salleh et al, 2007; Barret, 2009). By way of illustration, group activities rated the highest out of the classroom activities that the students participated in. Qualitative feedback from the students also highlighted that they valued communicative and interactive learning activities more than the traditional lecture-led method of learning (Kivela \& Kivela, 2005).

Additional, Savin-Baden (2003) believed that PBL helped to develop criticality of learners and the students may be better able to integrate basic science knowledge into the solutions. A promising recent development in tertiary education involves the application of PBL as a curricular vehicle to develop student talent. According to Brownell and Jameson (2004), PBL has been used for a decade in one graduate management program. PBL capitalizes on synergies among cognitive, affective and behavioural learning. Although management education usually privileges cognitive learning, affective learning is equally important. It is hard to disagree with Brownell and Jameson (2004), by focusing on real-world problems, PBL helps students appreciate multiple perspectives, recognize non-rational elements of decision making, and confront ethical quandaries. Together, cognitive and affective learning underpin the essential third element: behavioural learning about how to implement plans, lead teams, resolve conflict, persuade others, and communicate with multiple constituencies. Specific examples of PBL projects illustrate this inner relationship.

On the whole, from this PBL literature review discussion, the types of problems and how this problem should be solved can influence students' thinking and how they gain knowledge. Due to that, problem and problem solving process are the main characteristics in PBL. Therefore, it can be used to explain both issues.

\section{PROBLEM-BASED LEARNING DIFFICULTIES}

Successful implementation of PBL does not come easily. All our strengths and skills as teachers will be required. Complex difficulties may arise and according to Todd (1991: 132) the difficulties are; (i) teachers' role change - the teachers' inability to understand thoroughly the extended of the role change they are going to have to make, and to see how this might affect the satisfaction they find in teaching and their feelings of being 'valued' as teachers; (ii) students' role conflict - students may have helped to see the relevance and the benefits of PBL, the reality can sometimes be too much in conflict with their habits and expectations of learning. This is especially true of school leavers who, unless introduced carefully and gradually to the process and given the opportunity to acquire successful learning skills early in the course, can actively resist the new approach; (iii) colleagues' reactions - this is especially important for individuals or small groups who decide to use the PBL technique when the rest of the faculty retains traditional lecturing methods with the same students. Reactions experienced can be: lack of support, total disinterest, or patronizing behaviour. PBL may be seen as self-indulgent and time-wasting; (iv) keeping the team together - this can be difficult but is vital for any group implementing PBL. Serious differences can easily emerge in interpretation of the philosophy as well as the practical realities. Teachers need to be aware of these possibilities and develop strategies for supporting each other and uniting the group and; (v) developing process skill 
- the teaching of process skills, especially thinking and problem-solving skills is difficult for many teachers who may not have developed these skills fully themselves. If they feel inadequate they may not put enough emphasis on the students developing and practising these important processes. Without the direction, the support and the confidence which problem-solving strategies and process skills give the students, they can often fail.

Added to this, one of the most difficult aspects of beginning PBL based on Holliester's (1997: 3) opinion is deciding just how to go into the problem. It is true that, as a teacher we seem to be content with the superficial levels of PBL. Sometimes, teachers think that PBL is really about being creative and brainstorming problems and their possible solution. Another way to looking at this is that the creative and original solution isn't necessarily the best. However, there are a lot of critical thinking skills on the part of both teacher and student which are necessary to strip away the layers of a problem so it doesn't just stay a superficial level of creative brainstorming.

\section{REVIEW OF CRITICAL THINKING SKILL}

Critical thinking has often been thought as a prevalent topic of discussion within the educational realm nowadays. The concept has received a lot of attention because of its widely recognised role in the school reality. At the same time, there is an urgent need to clarify various issues involved in critical thinking, as the concept's painstaking character leaves space for various kinds of understanding and interpretation.

It has been widely accepted that critical thinking is an important and vital topic in modern education and all educators are interested in teaching critical thinking to their students (Schafersman 1991). In actual fact, the purposes of specifically teaching critical thinking in the business education or any other education disciplines is to improve the thinking skills of students and also to prepare them in the challenging world.

This is true if we use the view by Norman (1980) that it is strange that we expect students to learn, yet we seldom teach them anything about learning. According to Lochhead and Clement (1980), we should be teaching students how to think. Instead we are teaching them what to think.

Specifically, in an attempt to organise the topics covered by the critical thinking literature, this literature review will come up with two general categories pertaining to critical thinking: its nature, and instruction. Those include other sub-themes, which are presented later. The present section is an attempt to draw the extant picture of critical thinking from an educational perspective. That means that the presupposition underlying the presentation which follows is that critical thinking plays an essential role in schooling, and is an object of learning; research should focus on the discovery of the most effective instructional method for its development and promotion.

Critical thinking is significant to the actualisation of the above. It prepares the student with the necessary tools for responding to the changes and new challenges arising. It facilitates the execution of the individual tasks involved in such a process, by providing, for example, the method to handle large volumes of information, to evaluate judgements; it enables the students to make their own conclusions. Moreover, critical thinking promotes flexibility in the sense of adjustment to the current circumstances by involving mechanisms of generating knowledge and supporting the adoption of multiple perspectives. Concerning also the personal sphere, critical thinking promotes self-insight and awareness of the societal frames, thus contributing to the harmonious development of the self. According to Zhang (2007), theorist and educators in the field of learning theories have offered various definitions to describe the nature of critical thinking.

The definitions of critical thinking as reasonable and reflective thinking focused on deciding what to believe or do (Ennis, 1987), better thinking (Perkins, 1987); distinguish between thinking that is directed at adopting versus clarifying a goal (Nickerson, 1987).

Watson and Glaser (1980) define the concept of critical thinking as the unity of attitude, knowledge and ability which comprise (i) curiosity and ability to identify the existence of problems and accepting the evidence which support what is considered as true, (ii) knowledge of conditions to construct a valid conclusion, (iii) generating ideas and generalisations which are supported by logical evidence and (iv) the ability to apply the attitude and knowledge above. This means that the new information will be first analysed and assessed with various critical thinking skills and supported with logical reasoning before it is accepted and used. 
This definition is useful as it draws attention to a feature of critical thinking on which teachers and researchers in the fields seem to agree on, that the only realistic way to develop one's critical thinking ability is metacognition, and consciously aiming to improve it by reference to some model of good thinking in that domain (Fisher 2001). Although there are different definitions, it is agreed that critical thinking involves dispositions, creative thinking, problem solving, decision making, and metacognition (Ennis, 1987; McBride, 1991; Tishman \& Perkins, 1995).

This definition leads to the conclusion that critical thinking is the practice of processing this information in the most skilful, accurate, and rigorous manner possible, in a way that it will lead to the most reliable, logical, and trustworthy conclusions, by which one can make responsible decisions about one's life, behaviour and actions with full knowledge of assumptions and consequences of those decision.

Critical thinking has been considered one of the central goals in all levels of education and it has generated a wealth of literature. Theories and educators in the field agree that the characteristics of critical thinking is defining problems; asking appropriate questions; analyzing assumptions; synthesizing information; evaluating results. According to Molitor and George (1976), critical thinking consists of three abilities; (i) ability to collect data and to use the correct senses to choose related information, (ii) ability to analyze the data and to process the data, to classify, to make inferences, to make forecasts, to validate and to design hypothesis, and (iii) ability to take action on information and to solve a problem.

In the same way, good or effective critical thinkers as mentioned by Beyer (1987) were the ability to; (i) distinguish between verifiable facts and value claims; (ii) distinguish relevant from irrelevant information, claims, and reasons; (iii) determine factual accuracy of a statement; (iv) determine the credibility of a source; (v) identify ambiguous claims or arguments; (vi) identify unstated assumptions; (vii) detect bias; (viii) identify logical inconsistencies in a line of reasoning; (ix) recognize logical inconsistencies in a line of reasoning; and (x) determine the strength of an argument or claim.

This is true up to a point put forward by Facione (1990:2);

"...that critical thinking is understood to be purposeful, self-regulatory judgements which result in interpretation, analysis, evaluation and inference, as well as explanation of the evidential, conceptual, methodological, criteriological or contextual considerations upon which that judgement is based".

In order to promote students to think critically, one must employ primarily these components; the core critical thinking skills (Facione, 2006) which are;

(i) To create inference - to identify and secure elements needed to draw reasonable conclusions; to form conjectures and hypotheses; to consider relevant information and to deduce the consequences flowing from data, statements, principles, evidence, judgments, beliefs, opinions, concepts, descriptions, questions, or other forms of representation;

(ii) To investigate assumption - all reasoning must begin somewhere i.e some things must be taken for granted. Any "defect" in the assumptions or presuppositions with which the reasoning begins is a possible source of problems in student reasoning. Assessing skills of reasoning involves assessing their ability to recognize and articulate their assumptions, again according to the relevant standards. The student's assumptions may be stated clearly or unclearly; the assumptions may be justifiable or unjustifiable, crucial or extraneous, consistent or contradictory);

(iii) To make deduction (logical/reasoning) - the two methods of reasoning are deductive (facts, certainty, syllogisms, validity, truth of premises sound arguments and conclusions) and inductive (diverse facts, probability, generalizations, hypotheses, analogies inductive strength);

(iv) To make interpretation - comprehend and express meaning or significance of wide variety of experiences, situations, data, events, judgments, conventions, beliefs, rules, procedures, or criteria; and

(v) To make judgement (evaluation) - assess the credibility of statements or other representations which are accounts or descriptions of a person's perception, experience, situation, judgment, belief, or opinion; and to assess the logical strength of the actual or intended inferential relationships among statements, descriptions, questions, or other forms of representation. 
These were identified by a Delphi method, when a panel of 46 individuals from a variety of academic disciplines participated in a study carried out on behalf of the American Philosophical Association (APA). Their consensus statement is reproduced by Facione (2006, p. 21).

\section{CRITICAL THINKING IN TERTIARY EDUCATION AND TEACHING APPROACH IN MALAYSIA}

The development of critical thinking has been a fundamental goal in education in Malaysia. The Malaysian government has encouraged the use of these skills in higher education institutions through the introduction of Soft Skills. The government has identified human capital development as the most critical element in achieving its Vision 2020. Human capital development encompasses a holistic acquisition of knowledge, skills and attitude, complemented by soft skills capabilities. Soft or generic skills refer to the cluster of personality traits, social graces, language proficiency, personal habits and team work. Accordingly, the Ministry of Higher Education, Malaysia has explicitly identified seven elements of soft skills (Mohd Majid et al, 2008) that included communications' skills, problem solving and thinking skills, continuous learning skill and information management skills, work in group skills, leadership skills, professional ethics and entrepreneurship skills

Before the introduction of Soft Skills, Malaysian students already have experience with problem solving and creative and critical thinking teaching through New Curriculum for Primary School (Kurikulum Baru Sekolah Rendah, KBSR) and New Curriculum for Secondary School (Kurikulum Baru Sekolah Menengah, KBSM), but it is not detailed.

Accordingly, critical and creative thinking became main goals for education in Malaysia. Education Act (1996) also focused on thinking skills through,

"... an educational programme that includes curriculum and co-curricular activities which encompasses all the knowledge, skills norms, values, cultural elements and beliefs to help develop a pupil fully with respect to the physical, spiritual, mental and emotional aspects as well as to inculcate and develop desirable moral values and to transmit knowledge". Education Act 1996 [Education (National Curriculum) Regulation 1997]

Thus, Educational Development Main Plan (Pelan Induk Pembangunan Pendidikan 2006-2010) also brings a focus on thinking skills:

"Education plays an important role in developing human capital with a strong identity, competence, positive attitude, knowledgeable and high-skilled in order to fulfil the needs of the developed nation in 2020. The human capital to be cultivated should be able to think critically and creatively, to solve problems, having the capacity to create new opportunities, having the resilience and the ability to face the changing global environment".

Accordingly, critical and creative thinking became main goals for education in Malaysia. The Malaysian educational reform's components; curriculum, training programs, research, university subjects' curricula were to be designed to focus on development of students' critical thinking abilities. The basic principle, the development of student critical thinking was a main agenda of (University Pendidikan Sultan Idris, Malaysia (UPSI) that was chosen to plan the business education curriculum.

\section{THE IMPORTANCE OF CRITICAL THINKING SKILLS}

The aim of the National Education Philosophy, Malaysia (1996) is to develop individuals who are intellectually, spiritually, emotionally and physically balanced and harmonic, based on a firm belief in and devotion to God. In this context the lecturers should understand and have a deep awareness in the National Education Philosophy as the implementation of thinking skills are based on the core of this philosophy. The implementation of thinking skills in this study means that the lecturers will implement the thinking skills integrative in teaching the contents of Entrepreneurship course using a well-planned method.

The ability to think critically is an outcome generally expected of graduates from tertiary education. According to Paul and Elder (2005), critical thinking had become important due to four trends: accelerating change, intensifying complexity, escalating interdependence, and increasing danger. Critical thinking is an important issue 
in higher education and the development of critical thinking skills is one of the primary aims of an undergraduate degree. The Quality Assurance Agency for Higher Education in the United Kingdom states that a psychology student should be able to make crucial judgements and evaluations as part of their generic skills (The Quality Assurance Agency for Higher Education, 2002). One must acknowledge that critical thinking is a necessary skill for the full understanding of theories, evidence and the core issues and debates in the domain of psychology and other disciplines (Guiller et al, 2008). The mere acquisition of knowledge through memory is often not sufficient for effective learning. Learners need to make sense of what they have learned and know when, where and how to use knowledge. Understanding the knowledge acquired is, therefore, fundamental to effective learning in most cases. The key mental process in understanding is thinking. In Facione's (2006) opinion "people who are poor critical thinkers, who lack the dispositions and skill..., cannot be said to be liberally educated, regardless of the academic degrees they may hold".

Critical thinking is a skill that most teachers would readily agree is important for students to develop. Unfortunately, many of our students have poorly developed critical thinking skills - the problem is rooted in those who teach.

\section{CRITICAL THINKING TEACHING STRATEGIES}

The teaching of thinking skills began in the United States on 1980 with critical thinking skills and it was followed with creative and critical thinking skills in 1985. In 1990, the teaching of creative and critical thinking skills was developed to meta-cognitive reflection about learning (Fogarty \& McTighe, 1993). It has been widely accepted that critical thinking cannot be taught by lecturing but Fisher (2005) believed that the thinking skills tradition argues that thinking skills can be taught and should be taught. According to Rudd (2007), good thinking skills will not develop on their own, they must be taught. Teaching thinking skills is a difficult endeavour. Teaching to promote thinking takes much time to prepare, is difficult to plan, and limits the amount of content 'taught'.

Swartz and Parks, cited by Innabi and El Sheikh (2006), suggest that there are two approaches to teach critical thinking using content disciplines; a) the embedded approach - where the critical thinking skills are taught in indirect ways without spelling it out to students; and b) the infusion approach where critical thinking skills are taught manifestly using the discipline's content. Questioning is one of the strategies used to enhanced critical thinking and this has been used in Socratic teaching. It is quite right, according to Paul and Elder (2003), that this type of questioning seeks to clarify information, to identify a point of view, to discover assumptions, to differentiate factual claims from value judgements, and to detect flaws in reasoning by asking students questions and not by giving them answers. More specifically, Banning (2005) agree that by asking metacognitive questions, this may stimulate students to think critically. Flavell cited by Noushad (2008) viewed metacognition as "knowledge and cognition about cognitive phenomena". Metacognition is often referred to in the literature as "thinking about one's own thinking", or as "cognitions about cognitions". It is usually related to learners' knowledge, awareness and control of the processes by which they learn and the metacognitive learner is thought to be characterized by the ability to recognize, evaluate and, where needed, reconstruct existing ideas. More importantly, when his/her metacognitive ability has been sufficiently developed, the student's 'inner disciplined voice' would preclude the need for any 'Socratic questioner'.

In the words of Burris (2005), the most effective way to improve the ability of students to think critically is through appropriate teaching methodologies. In other words, the instructional strategies will affect knowledge acquisition and critical thinking skills. However, it should not be forgotten that PBL is an instructional strategy that favours a more constructivist approach. In the same way, learning occurs when students construct their own knowledge by solving authentic problem and reflecting on their own experiences.

This literature review will assume that PBL method will stimulate teaching and learning. Problem is the main focus of teaching and learning that will happen through problem solving activities. Declarative knowledge and skills that are gained through critical thinking skills will be applied to solve a problem. This process is repeated, so the knowledge and skills will be easy to memorize and it will be kept in long-term memory. It will be easy to recall when it is needed and it is an automatic process. 


\section{DEFINING THE RESEARCH GAP}

Based on its success in other disciplines, PBL would appear to offer benefits for business education. However, there seems to be slow progress from business teachers to introduce this approach into their subjects (Banta et al, 2002; Bigelow, 2004). Based on a study by Bigelow (2004), only six business courses had implemented this pedagogy among 106 higher educational institutions that used PBL in 2001.

There have been many studies about the effectiveness of the PBL approach on students' critical thinking skills (Chin \& Chia, 2000; Neo \& Neo, 2001; Ward \& Lee, 2002; Kivela \& Kivela, 2005; Yuan et al, 2008), but these studies are mainly in the field of science and technology, especially in the medical, nursing, sciences, hospitality and engineering. There is a lack of PBL studies in business education especially in Malaysia. The most recent study in Malaysia regarding PBL had been conducted by Awang and Ramly (2008). This study indicated that PBL approach could improve the thinking skills of students, but the study had been conducted on engineering students. Another study is by Salleh et al (2007), also on engineering education. In this study, it was found that students in PBL classroom had improved in their mastery of the content area and generic skills. As for the study by Tan and Ng (2006), this looks at the students' ability to think and respond strategically towards new venture creation in entrepreneurship education in Singapore.

This literature review will be the first in Malaysia which focuses on the implementation of PBL method among lecturers to improve student critical thinking skills which is integrated into the business education courses. This literature review will include a qualitative study which uses the grounded theory approach. The data will be analysed constantly in order to explore and understand how business education lecturers and students inculcate the PBL method in applying problem solving skills and critical thinking skills in teaching and learning PPU1023 Entrepreneurship course. This literature review will also find out the views of business education lecturers and students on the importance of inculcating critical thinking skills, problems faced in implementing critical thinking skills in teaching and environmental factors which motivate business education lecturers and students to implement critical thinking skills in the teaching and learning of PPU1023 - Entrepreneurship at Faculty of Business and Economics, University Pendidikan Sultan Idris, Malaysia.

\section{CONCLUSION}

This literature review will prove that PBL method will stimulate teaching and learning. Problem is the main focus of teaching and learning that will happen through problem solving activities. Declarative knowledge and skills that are gained through critical thinking skills will be applied to solve a problem. This process is repeated, so the knowledge and skills will be easy to memorize and it will be kept in long-term memory. It will be easy to recall when it is needed and it is an automatic process.

There is a lot of literature on the development of PBL pedagogical approach in tertiary education. The PBL educational approach is known to have maximum positive impacts in producing professional competencies among graduates in many educational disciplines. However, there is limited discussion about PBL pedagogical approaches implemented in business education. This approach has not been established as a major pedagogical method in schools of business around the world. In spite of this, there are a few schools of business that use the implementation of PBL in their curriculum structures.

\section{REFERENCES}

1. Albanese, M. (2000). Problem-based learning: Why curricula are likely to show little effect on knowledge and clinical skills. Medical Education, 34 (9), pp. 729-738.

2. Armstrong, E. G. (1991). A hybrid model of problem-based learning. In D. Boud \& G. Feletti (Eds.), The challenge of problem-based learning. London: Kogan Page, Ch. 14, pp.137-149.

3. Awang, H., \& Ramly, I. (2008). Thinking skill approach through problem-based learning: Pedagogy and practice in the engineering classroom. International Journal of Social Sciences, 3 (1), pp. 18-23.

4. Banning, M. (2005). Approaches to teaching: Current opinions and related research. Nurse Education Today, 25, pp. 502-508. 
5. Banta, T., Black, K. \& Kline, K. (2002). Evidence for and against problem-bases learning, Newsletter for undergraduate problem-based learning, Stamford University, 3 (3), pp. 1-7.

6. Barret, T. (2009). What can we learn about learning from how problem-based learning students talked about it in PBL tutorials?. Invited Speaker will present in $2^{\text {nd }}$ International PBL Symposium. Singapore: Republic Polytechnic, 10-12 June. Retrieved January 10, 2009, from http://www.rp.sg/symposium/2009/abstract_barret.asp

7. Barrows, H.S. \& Tamblyn, R.M. (1980). Problem-based learning: An approach to medical education. New York: Springer Publishing Company, Inc.

8. Barrows, H. S. (1997). Problem-based learning is more than just learning based round problems. The Problem Log, 2 (2), pp. 4-5, Retrieved December 12, 2008, from http://pbln.imsa.edu/resources/articles/plog_1997-02-2.pdf

9. Bigelow, J. (2004). Using problem-based learning to develop skills in solving unstructured problems. Journal of Management Education, 28, pp. 591-609.

10. Biggs, J. (2003). Teaching for quality learning at university. Berkshire, UK: Open University Press.

11. Boud, D., \& Feletti, G. I. (1991). The challenge of problem-based learning. London: Kogan Page.

12. Boud, D., \& Feletti, G. (1997). Changing problem-based learning: Introduction to the second edition. In D. Boud \& G. Feletti (Eds.), The challenge of problem-based learning. $\quad$ London: Kogan Page, Ch. 1, pp. $1-16$.

13. Brownell, J. \& Jameson, D. A. (2004). Problem-Based Learning in Graduate Management Education: An Integrative Model and Interdisciplinary Application, Journal of Management Education, 28 (5), pp. 558577. Retrieved December 12, 2008, from http://jme.sagepub.com/cgi/content/abstract/28/5/558

14. Burch, K. (2001). PBL, Politics, and Democracy. In B. J. Duch, S. E.. Groh \& D. E. Allen (Eds), The power of problem-based learning: A practical "How To" for teaching undergraduate courses in any disciplines. Sterling, Virginia: Stylus Publishing, LLC, pp. 193-205.

15. Burris, S. (2005). Effect of Problem-Based Learning on Critical Thinking Ability and Content Knowledge of Secondary Agriculture, Unpublished PhD Dissertation. University of Missouri-Columbia, USA.

16. Camp, G. (1996). Problem-based learning: A paradigm shift or a passing Fad? Medical Education Online, 1(2), pp. 1-6. Retrieved November 22, 2008, from http://www.msu.edu/ dsolomon/f0000003.pdf

17. Chan, K.G. (2000). PBL@ Anderson. Problem-based learning: Educational innovation across disciplines. The $2^{\text {nd }}$ Asia Pacific Conference on PBL, Temasek Polytechnic, Singapore. Retrieved November 2, 2008, from http://pbl.tp.edu.sg/PBL-Resources/articles/understandingPBL/ChanKhahGek.pdf

18. Chin, C. \& Chia L.G. (2000). Implementing PBL in biology. Problem-based learning: Educational innovation across disciplines. The $2^{\text {nd }}$ Asia Pacific Conference on PBL, Temasek Polytechnic, Singapore. Retrieved November 22, 2008, from http://pbl.tp.edu.sg/PBLresources/articles/PBLSubjects/ChristineChinLiGekChia.pdf

19. Clarke, J. H. (1990). Patterns of thinking: Integrating learning skills in content teaching. Boston: Allyn \& Bacon.

20. Colliver, J. A. (2000). Effectiveness of problem-based learning curricula: Research and theory. Academic Medicine, 75 (3), pp. 259-266.

21. De Graaff, E., \& Kolmos, A., (2003), Characteristics of problem-based learning. International Journal of Engineering Education, 19 ( 5), pp. 8.

22. Delisle, R. (1997), How to use problem-based learning in the classroom. Association for Supervision and Curriculum Development. Alexandria, VA, USA.

23. Dewey, J. (1944). Democracy and Education: An Introduction to the Philosophy of Education. New York: The Free Press.

24. Dochy, F., Segers, M., Van den Bossche, P., \& Gigbels, D. (2003). Effects of problem-based learning: A meta-analysis. Learning and Instruction, 13, pp. 533-568.

25. Dolmans, D. (2003). The effectiveness of PBL: The debates continues. Some concerns about the BEME movement. Medical Education, 37, pp. 1129-1130.

26. Du, Xiangyun (2006). Gendered practices of constructing an engineering identity in a problem-based learning environment. European Journal of Engineering Education, 31, (1). pp. 35-42.

27. Education Act, (1996). Ministry of Education Malaysia, Kuala Lumpur.

28. Educational Development Main Plan (Pelan Induk Pembangunan Pendidikan 2006-2010). Ministry of Education Malaysia, Kuala Lumpur. 
29. Ennis, R. H. (1987). A Taxonomy of Critical Thinking Dispositions and Abilities. In J. B. Baron \& R. J. Sternberg (Eds.), Teaching Thinking Skills: Theory and Practice. New York: W. H. Freeman, pp. 9-26.

30. Facione, P. A. (1990). Critical thinking: A statement of expert consensus for purposes of educational assessment and instruction. Executive Summary "The Delphi Report”. Millbrae, CA, The California Academic Press.

31. Facione, P. A. (2006). Critical Thinking: What it is and why it counts. Insight Assessment, California Academic Press.

32. Farrow, R., \& Norman, G. (2003). The effectiveness of PBL: The debate continues. Is meta-analysis useful? Medical Education, 37, pp. 1131-1132.

33. Fisher, A. (2001). Critical Thinking: An Introduction. Cambridge University Press, pp. 5

34. Flint, W. J. (2007). PBL: Welcome to the "Real World" A Teaching Model for Adult Learner. US: Word Unlimited.

35. Fogarty, R., \& McTighe, J. (1993). Educating teachers for higher order thinking; the three story intellect. Theory into Practice, 32, pp. 161-169

36. Frenay, M., Galand, B., Milgrom, E., \& Raucent, B. (2007). Project and Problem based learning in the first two years of the engineering curriculum at UCLouvain. In A. Kolmos \& E. De Graaff (Eds). Management of change: Implementation of problem-based and project-based learning in engineering. Rotterdam: Sense Publisher, pp. 93-108.

37. Guiller, J., Durndell, A., \& Ross, A. (2008). Peer Interaction and critical thinking: Face-to-face or online discussion? Learning and Instruction, Vol. 18, pp. 187-200.

38. Hmelo-Silver, C., \& Lin, X. (2000). Becoming self-directed learners: Strategy development in problembased learning, In D. E. Evensen \& C. E. Hmelo (Eds), Problem-based learning: A research perspective on learning interactions. Mahwah, NJ: Lawrence Erlbaum Assoc., Inc., Publishers, pp. 227-250.

39. Hmelo-Silver, C. (2009). What do we know about problem-based learning? Current status and future prospects. Keynotes speaker will present in $2^{\text {nd }}$ International PBL Symposium. Singapore: Republic Polytechnic, 10-12 June. Retrieved January 10, 2009, http://www.rp.sg/symposium/2009/keynote hmelosilver.asp

40. Hollister, B. C. (1997). Stripping away layers of the opinion or tracking a problem. The Problem Log, 2 (2), pp. 3, Retrieved December 12, 2008, from http://pbln.imsa.edu/resources/articles/plog_1997-02-2.pdf

41. Innabi, H \& El Sheikh, O. (2006). The Change in Mathematics Teachers' Perceptions of Critical Thinking After 15 Years of Educational Reform in Jordan. Educational Studies in Mathematics, Vol. 64, pp. 45-68. Retrieved December 8, 2008, from http://springerlink.metapress.com/content/1573-0816

42. Kivela, J., \& Kivela, R. J., (2005). Student perceptions of an embedded problem-based learning instructional approach in a hospitality undergraduate programme. International Journal of Hospitality Management, 24 (3), pp. 437-464.

43. Kwan, C.Y. (2000). "What the problem-based learning (PBL): it is magic, myth and mindset". National University of Singapore Centre for Development of Teaching and Learning Brief, 3 (3), pp. 1-2.

44. Lemke, J. L. (2001). Articulating communities: Sociocultural perspectives on science education. Journal of Research in Science Teaching, 38(3), pp. 296-316.

45. Lochhead, J. \& Clement, J. (1980). Cognitive process instruction. Hillsdale, NJ: Lawrence Erlbaum. pp. 133-146

46. Maddocks, A. (2004). Personal development planning and portfolio building-introducing undergraduates to the processes of professional development. In C. Baillie, \& I. Moore, (Eds.), Effective learning and teaching in Engineering, London: Routledge, pp. 171-184.

47. Major, C. H., \& Palmer, B. (2001, Spring). Assessing the effectiveness of problem-based learning in higher education: Lessons from the literature. Academic Exchange Quarterly, 5 (1). Retrieved November 22, 2008, from http://www.rapidintellect.com/AEQweb/mop4spr01.htm

48. Margetson, D. (1991). Why is problem-based learning a challenge?. In D. Boud \& G. Feletti (Eds.), The challenge of problem-based learning. London: Kogan Page, Ch. 4, pp.42-50.

49. McBride, R. E. (1991). Critical Thinking: An Overview with Implications for Physical Education. Journal of Physical Education, Reacreation and Dance, Vol. 69 (7), pp. 112-125.

50. Mohd Majid Konting, Khatijah Yusoff and Sidek Ab Aziz (2008), Human Capital Development: Soft Skill Initiatives at Universiti Putra Malaysia. Journal of the World Universities Forum, 1(4), pp. 89-98. 
51. Molitor, L. L., \& George, K. D. (1976). Development of a Test of Science Process Skills. Journal of Research in Science Teaching, 13, pp. 405-412.

52. Morales-Mann, E. T., \& Kaitell, C. A. (2001). Problem-based learning in a New Canadian curriculum. Journal of Advanced Nursing, Vo. 33 (1), pp. 13-19.

53. National Education Philosophy (1996). Ministry of Education, Kuala Lumpur

54. Neo, T. K., \& Neo, M. (2001). Problem-based learning: Reconstructing a website using multimedia authoring tools. Retrieved November 13, 2008, from http://www.tp.edu.sg/pblconference/full/Neo\%20T.\%20K\%20and\%20Neo\%20M.pdf

55. Newman, M. (2003). A pilot systematic review and meta-analysis on the effectiveness of problem-based learning. On behalf of the Campbell Collaboration Systematic Review Group on the effectiveness of problem-based learning. Learning and Teaching Subject Network-01. Newcastle: LTSN. Retrieved December 2, 2008, from http://www.ltsn-01.ac.uk/resources/features/pbl

56. Newman, M., Van den Bossche, P., Gijbels, D., McKendree, J., Roberts, T., Rolfe, I., et al (2004). Responses to the pilot systematic review of problem-based learning. Medical Education, 38, pp. 921-923.

57. Nickerson, R. S. (1987). "Why teach thinking?," in J. B. Baron and R. J. Sternberg (Eds.), Teaching Thinking Skills: Theory and Practice. New York: W. H. Freeman, pp. 27-37.

58. Norman, D. (1980). Cognitive Engineering and Education. In D.T. Tuna \& F. Reif (Eds), Problem Solving and Education: Issues in Teaching and Research, Erlbaum Publishers.

59. Norman, G. R., \& Schmidt, H. G. (1992). The Psychologist Basis of Problem-Based Learning: A Review of the Evidence. Academic Medicine, 67, pp. 557-565.

60. Noushad, P. P. (2008). Cognitions About Cognitions: The Theory of Metacognition. ERIC, ED502151. Retrieved December 12, 2008, from http://www.eric.ed.gov/ERICDocs/data/ericdocs2sq1/content_storage_01/0000019b/80/3e/70/36.pdf

61. Paul, R. \& Elder, L. (2003). A Miniature Guide for Those Who Teach. On How to Improve Students Learning: 30 practical ideas. California: Foundation for Critical Thinking.

62. Paul, R. \& Elder, L. (2005). A Guide for Educators to Critical Thinking Competency Standards: Standards, Principles, Performance, Indicators, and Outcomes with Critical Thinking Master Rubric, Foundation for Critical Thinking. Retrieved October 12, 2008, from http://www.criticalthinking.org

63. Perkins, D.N. (1987). Thinking Frames: An Integrative Perspective on Teaching Cognitive Skills. In Baron, J.B. \& Sternberg, R.J. (Eds.), Teaching Thinking Skills: Theory and Practice. New York: W.H. Freeman \& Company, pp. 41-61.

64. Phillips, J.A. (1997). Teaching thinking skills; Theory and practice (Pengajaran kemahiran berfikir: Teori dan amalan). Kuala Lumpur: Utusan Publications \& Distributors.

65. Rudd, R. D. (October, 2007). Defining Critical Thinking, Techniques (ACTE), 82, (7), pp. 46-49. Retrieved November 2, 2008, from http://www.acteonline.org

66. Salleh, M. B., Othman, H., Esa, A., Sulaiman, A., \& Othman, H. (2007). Adopting problem-based learning in the teaching of engineering undergraduates: A Malaysian experience, International Conference on Engineering Education, Portugal: Coimbra, September, 3-7. Retrieved January 15, 2009, from http://icee2007.dei.uc.pt/proceedings/papers/243.pdf

67. Savery, J.R., \& Duffy, T.M. (1995). Problem-based learning: An instructional model and its constructivist framework. Educational Technology, 35 (5), pp. 31-38.

68. Savin-Baden, M. (2000). Problem-base learning in higher education: Untold stories. Buckingham, UK: Open University Press/SRHE.

69. Savin-Baden, M. (2003). Facilitating PBL : Illuminating perspectives. London: The Society for Research into Higher Education \& Open University Press.

70. Schafersman, S. D. (1991). An Introduction to Critical Thinking. Retrieved December 22, 2008, from http://www.freeinquiry.com/critical-thinking.html

71. Schmidt, H. G. (1983). Problem-based learning: Rationale and description. Medical Education, 17, pp. 1116.

72. Silen, C. (2009). Self-directed learning as learning process and a learning outcome. Invited Speaker will present in $2^{\text {nd }}$ International PBL Symposium. Singapore: Republic Polytechnic, 10-12 June. Retrieved January 10, 2009, from http://www.rp.sg/symposium/2009/abstract_silen.asp

73. Spence, L. (2004). The usual doesn't work: Why we need problem-based learning. Portal: Libraries and the Academy, 4 (4), pp. 485-493. 
74. Syed Anwar A. M. A. B. (2002). The effect of problem-based learning with structured scaffolding on knowledge performance, reasoning performance and constructive learning dynamism in matriculation chemistry (Kesan kaedah pembelajaran berasaskan masalah dengan perancahan berstruktur terhadap prestasi pengetahuan, prestasi taakulan dan dinamisme pembelajaran konstruktivis dalam kimia matrikulasi). Unpublished PhD dissertation, Penang: Universiti Sains Malaysia.

75. Tan, O. S. (2007). Problem-based learning pedagogies: psychological processes and enhancement of intelligences. Educational Research Policy Practices, 6, pp. 101-114.

76. Tan, S. S., \& Ng, C. K. F. (2006). A problem-based learning approach to entrepreneurship education. Journal of Education and Training, 48 (6), pp. 416-428. Retrieved December 21, 2008, from http://www.emeraldinsight.com/0040.0912.htm

77. The Quality Assurance Agency for Higher Education (2002). Psychology honours degree benchmark statement. Gloucester, UK: Cambridge University Press.

78. Tishman, S., \& Perkins, D. (1995, August). Critical thinking and physical education. Journal of Physical Education and Recreational Dance. 66 (6), pp. 24-30.

79. Tiwari, A. (2009). Facilitating student learning during problem-based learning tutorials. Invited Speaker will present in $2^{\text {nd }}$ International PBL Symposium. Singapore: Republic Polytechnic, 10-12 June.

Retrieved January 10, 2009, from http://www.rp.sg/symposium/2009/abstract tiwari.asp

80. Todd, S. (1991). Preparing tertiary teachers for problem-based learning. In D. Boud \& G. Feletti (Eds.), The challenge of problem-based learning. London: Kogan Page, Ch. 13, pp.131-136.

81. Ward, J. D., \& Lee, C. L. (2002). A review of problem-based learning. Journal of Family and Consumer Sciences Education, 20 (1), pp. 16-26. Retrieved November 12, 2008, from http://www.bie.org/files/Ward\%20\&\%20Lee_A\%20Review\%20of\%20Problem-Based\%20Learning.pdf

82. Watson, G.B. \& Glaser, E.M. (1980). Watson-Glaser Critical Thinking Manual. San Antonio: The Psychological Corporation, Harcourt Brace \& Co.

83. Yeo, R. K. (2007). (Re)viewing problem-based learning: An exploratory study on the perceptions of its applicability to the workplace. Journal of Managerial Psychology, 22 (4), pp. 369-391.

84. Yuan, H. B., Kunaviktikul, W., Klunklin, A., \& Williams, B. A. (2008). Improvement of nursing students' critical thinking skills through problem-based learning in the People's Republic of China: A quasiexperiment study. Nursing and Health Sciences, 10, pp. 70-76.

85. Zhang, L. (Summer, 2007). Promoting Critical Thinking, and Information Instruction in a Biochemistry Course, Issues in Science and Technology Libraryship. Retrieved December 1, 2008, from http://www.istl.org/07-summer/refereed/html 